\title{
Mediating Roles of the Cooperating Teachers' Self-Efficacy to the Pre-Service Teachers' Classroom Instruction and Evaluation
}

\section{Andrian A. Dela Cruz ${ }^{1}$ Reymond S. Vasquez ${ }^{2}$ (D)}

'Assistant Professor, College of Teacher Education, Abra State Institute of Sciences and Technology, Abra, Philippines.

Email:andrian_delacruz10@yahoo.com

'Associate Professor, College of Arts and Sciences, Abra State Institute of Sciences and Technology, Abra, Philippines.

Email:reymondvasquez990@yahoo.com

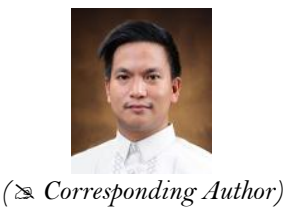

( Corresponding Author)

\begin{abstract}
This study determined the mediating roles of cooperating teachers' self-efficacy to pre-service teachers' classroom instruction and evaluation and their performance in practice teaching. The sample consisted of twenty-one cooperating Kindergarten teachers and twenty-one pre-school education (PSEd) pre-service teachers. This study employed descriptive-investigatory research. Cooperating teachers have a strong determination to deal with academic-related challenges which they encounter, and also to manage personal conflicts, but they do not compromise being openminded to someone opposing them. The pre-service teachers meet the standards set by the college regarding the different competencies in preparation for the actual teaching. They do best in the preparation of teaching aids, while their ability to answer questions during actual demonstration teaching should be improved. The General Self-Efficacy (GSE) of the cooperating teachers does not mediate with the level of pre-service teachers' classroom instruction and evaluation performance. The teaching and management skills of the future teachers are brought about by the high self-efficacy of their cooperating teachers in a mediating role.
\end{abstract}

Keywords: General Self-efficacy (GSE), Mediating roles, Cooperating teachers, PSEd pre-service teachers, Classroom instruction and evaluation.

Citation | Andrian A. Dela Cruz; Reymond S. Vasquez (2020). Mediating Roles of the Cooperating Teachers' Self-Efficacy to the Pre-Service Teachers' Classroom Instruction and Evaluation. Journal of Education and e-Learning Research, 7(2): 195-202. History:

Received: 24 April 2020

Revised: 28 May 2020

Accepted: 30 June 2020

Published: 14 July 2020

Licensed: This work is licensed under a Creative Commons

Attribution 3.0 License (c) E E

Publisher: Asian Online Journal Publishing Group
Acknowledgement: Both authors contributed to the conception and design of the study.

Funding: This study received no specific financial support.

Competing Interests: The authors declare that they have no conflict of interests.

Transparency: The authors confirm that the manuscript is an honest, accurate, and transparent account of the study that was reported, that no vital features of the study have been omitted, and that any discrepancies from the study as planned have been explained.

Ethical: This study follows all ethical practices during writing

\section{Contents}

1. Introduction

2. Materials and Methods 


\section{Contribution of this paper to the literature}

This study contributes to existing literature by determining the mediating roles of the cooperating teachers' self-efficacy to the pre-service teachers' classroom instruction and evaluation and their performance in practice teaching.

\section{Introduction}

The role of educators in securing quality education and developing a lifelong achievement for learners is crucial. The layman's saying, "We cannot give what we do not have," is a repeated thought which is very relevant in the field of education. A student cannot be expected to attain a level of competence greater than that which their teachers possess.

Experience is one of the essential indicators that pre-service teachers in the field must continually improve. There are, indeed, good and bad experiences, either before or during a teacher's practicing career, that could affect their teaching readiness and effectiveness. Cheng (2013) pointed out that the role of the educational institution is substantial for teachers. Garvis and Keogh (2011) reiterated that the undergraduate program of student-teachers could help improve their teaching efficacy in the future. Molnar (2008) various researches have been conducted and continuously cited as an essential concept in the field of education.

The notion of whether a teacher can accomplish something in the teaching-learning process is known as teaching efficacy (Montebon, 2015). Teaching efficacy, as defined by Bandura (1995), is someone's belief in their capacity to organize and perform the courses of action necessary to achieve and complete the teaching-learning task successfully. The significant role of self-efficacy in schooling was stressed in the study of Tschannen-Moran, Hoy, and Hoy (1998) and, as reiterated in the study by Inceçay and Dollar (2013), argued that greater self-efficacy leads to better performance and the greater efficiency of teachers.

Various studies have revealed the impact of self-efficacy on teachers' instructional competency in the teaching and learning scenario, and this impact has intrigued scholars for several decades (Muijs \& Rejnolds, 2001; Nauta, 2004). The notion that teachers can improve the student's progress was stressed in the findings of Muijs and Rejnolds (2001). On the other hand, Martin and Marsh (2006); Skaalvik and Skaalvik (2004) noted in their study the relationship between and among self-efficacy, beliefs, students' achievements, readiness, and persistence, including teacher commitment. The increase in teacher readiness, the influence of classroom experience, and the predicted teaching effectiveness were explained in the studies of Baker (2002); Liaw (2009) and Anthony and Said (2008).

Despite the ample studies revealing the effect of teachers' self-efficacy and academic performance, these studies have neglected to mediate the cooperating teachers' general self-efficacy and the future teachers' classroom instruction and evaluation performances. Thus, the researchers were prompted to conduct this study to reveal the mediating roles of cooperating teachers' self-efficacy and future teachers' performances in the teaching-learning process.

\section{Materials and Methods}

Descriptive-investigatory research methods were employed in this study. Descriptive, because it determined the level of GSE of the cooperating teachers and the practice teaching performance of the pre-service teachers in terms of classroom instruction during demonstration teaching, and the evaluation given by their cooperating teachers. Likewise, it investigated the mediating role of the GSE of the cooperating teachers on the pre-service teachers' performance. The respondents were twenty-one (21) cooperating kindergarten teachers and the twentyone (21) PSEd pre-service teachers from various cooperating schools in the Schools Division of Abra, the Philippines, for the academic year 2017-2018.

To gather the necessary data, three instruments were adapted. The Teachers' Sense of Efficacy Scale of Tschannen-Moran and Hoy (2001) questionnaire was utilized to find the GSE of the cooperating teachers. Additionally, to determine the level of practice teaching performance of the pre-service teachers' in terms of classroom instruction and evaluation, the Evaluation Sheet for Classroom Instruction and the Performance Rating Form for Student Teachers of the College of Teacher Education of the ASIST-Bangued Campus were employed. In the analysis and interpretation of data, weighted mean, and bivariate analysis were used.

\section{Results and Discussion}

This section explains the results and discussion based on the data gathered in this study.

Problem 1. What is the level of the cooperating teachers' GSE?

Table 1 discloses the level of the cooperating teachers' GSE. Generally, the pre-service cooperating teachers claimed that they were not yet at the peak of their self-efficacy, as indicated by the rating, mean $=3.22$, they obtained. They rated themselves to be at a Moderately True (MT) level. However, the table revealed that almost all of the mentioned indicators measuring their self-efficacy were Exactly True (ET) with the highest mean of 3.40, along with the ability to handle whatever came their way. This only proves that cooperating teachers have a strong determination to deal with any challenges, either academic-related concerns or personal conflicts.

The finding corroborates that of Guo, Connor, Yang, Roehrig, and Morrison (2012), that when teachers have a high level of self-efficacy, they can provide and support their students' needs for learning, which ensures a more positive and conducive classroom environment. Further, Mahler, Großschedl, and Harms (2017) argued that successful teachers have professional competence, which includes teachers' motivational orientations embodying unique domains regarding self-efficacy and enthusiasm for teaching the subject. An article posted by Cherry (2018) reiterates that high self-efficacy guides people to solve challenging situations, participate in any activities well, develop a good sense of commitment, and recuperate from bad experiences. 
Table-1. Cooperating teachers' general self-efficacy (GSE).

\begin{tabular}{|c|c|c|c|c|}
\hline \multicolumn{3}{|c|}{ Cooperating Teachers' General Self-Efficacy (GSE) } & Mean & DR \\
\hline \multicolumn{3}{|c|}{ 1. I can always manage to solve difficult problems if I try hard enough. } & 3.33 & ET \\
\hline \multicolumn{3}{|c|}{ 2. If someone opposes me, I can find the means and ways to get what I want. } & 2.71 & $\mathrm{~T}$ \\
\hline \multicolumn{3}{|c|}{ 3. It is easy for me to be firm to my aims and accomplish my goals. } & 3.05 & MT \\
\hline \multicolumn{3}{|c|}{ 4. I am confident that I could deal efficiently with unexpected events. } & 3.29 & ET \\
\hline \multicolumn{3}{|c|}{ 5. Thanks to my creativity, I know how to handle unforeseen situations. } & 3.43 & ET \\
\hline \multicolumn{3}{|c|}{ 6. I can solve most problems if I invest the necessary effort. } & 3.29 & ET \\
\hline \multicolumn{3}{|c|}{ 7. I can remain calm when facing difficulties because I can rely on my coping abilities. } & 3.33 & ET \\
\hline \multicolumn{3}{|c|}{ 8. When I am confronted with a problem, I can usually find several solutions. } & 3.29 & ET \\
\hline \multicolumn{3}{|c|}{ 9. If I am in trouble, I can usually think of a solution. } & 3.10 & MT \\
\hline \multicolumn{3}{|c|}{ 10. I can usually handle whatever comes my way. } & 3.40 & ET \\
\hline \multicolumn{3}{|l|}{ Total Mean } & 3.22 & MT \\
\hline \multicolumn{5}{|l|}{ Norm: } \\
\hline Point Values & Statistical Limit & \multicolumn{3}{|c|}{ Descriptive Rating (DR) } \\
\hline 4 & $3.25-4.00$ & \multicolumn{3}{|c|}{ Exactly True (ET) } \\
\hline 3 & $2.50-3.24$ & \multicolumn{3}{|c|}{ Moderately True (MT) } \\
\hline 2 & $1.75-2.49$ & \multicolumn{3}{|c|}{ Hardly True (HT) } \\
\hline 1 & $1.00-1.74$ & \multicolumn{3}{|c|}{ Not all True (NaT) } \\
\hline
\end{tabular}

However, the indicator if someone opposes me, I can find the means and ways to get what I want, with the lowest mean of 2.71, was described as "Moderately True." The low mean score explains that these professionals are open-minded and respect the opinions of their peers, as shown by them listening to someone opposing them. DesMarais (2012) stated that, according to science, the ability to persuade others is a valuable skill. It can translate into significant outcomes, convincing people to follow your leadership, getting a raise, or countless other successes in the business realm. Further, as explained in the study of Mojavezi and Tamiz (2012), the higher a teacher's selfefficacy is, the higher student motivation would become.

Problem 2. What is the level of pre-service teachers' classroom instruction and evaluation in terms of a. teacher, b. teaching procedure, c. students, and d. general observation?

Table-2. Pre-service teacher classroom instruction and evaluation (N=21).

\begin{tabular}{|c|c|c|}
\hline Classroom Instruction & Mean & Descriptive Rating (DR) \\
\hline \multicolumn{3}{|l|}{ A. Teacher } \\
\hline 1. Teaching personality & 4.33 & Excellent (E) \\
\hline 2. Composure & 4.26 & Excellent (E) \\
\hline 3. Articulation & 4.05 & Very Good (VG) \\
\hline 4. Modulation of voice & 4.43 & Excellent (E) \\
\hline 5. Mastery of the medium of instruction & 4.12 & Very Good (VG) \\
\hline 6. Mastery of the subject matter & 4.02 & Very Good (VG) \\
\hline 7. Ability to answer & 1.64 & Fair $(\mathrm{F})$ \\
\hline 8. Openness to student opinion & 3.33 & Very Good (VG) \\
\hline Sub Mean & 3.77 & Very Good (VG) \\
\hline \multicolumn{3}{|l|}{ B. Teaching procedure } \\
\hline 1. Organization of the subject matter & 4.19 & Excellent (E) \\
\hline 2. Ability to relate subject matter with other fields & 3.19 & Good $(\mathrm{G})$ \\
\hline 3. Ability to provoke critically & 3.76 & Very Good (VG) \\
\hline 4. Ability to motivate & 4.19 & Excellent $(\mathrm{E})$ \\
\hline 5. Ability to manage the class & 3.98 & Very Good (VG) \\
\hline 6. Question technique & 3.88 & Very Good (VG) \\
\hline 7. Use of teaching aids & 4.50 & Excellent $(\mathrm{E})$ \\
\hline Sub Mean & 3.96 & Very Good (VG) \\
\hline \multicolumn{3}{|l|}{ C. Students } \\
\hline 1. Class attention & 4.21 & Excellent $(\mathrm{E})$ \\
\hline 2. Class participation & 4.36 & Excellent (E) \\
\hline Sub Mean & 4.29 & Excellent (E) \\
\hline \multicolumn{3}{|l|}{ D. General observations } \\
\hline 1. Rapport between teacher and students & 4.31 & Excellent (E) \\
\hline 2. Class atmosphere & 4.45 & Excellent $(\mathrm{E})$ \\
\hline 3. Overall teacher impact & 4.24 & Excellent $(\mathrm{E})$ \\
\hline 4. General classroom atmosphere & 4.36 & Excellent (E) \\
\hline Sub Mean & 4.34 & Excellent (E) \\
\hline General Mean & 4.09 & Very Good (VG) \\
\hline \multicolumn{3}{|l|}{ Norm: } \\
\hline Point Values & Statistical Limit & Descriptive Rating (DR) \\
\hline 5 & $4.15-5.00$ & Excellent $(\mathrm{E})$ \\
\hline 4 & $3.32-4.14$ & Very Good (VG) \\
\hline 3 & $2.49-3.31$ & $\operatorname{Good}(\mathrm{G})$ \\
\hline 2 & $1.66-2.48$ & Fair $(\mathrm{F})$ \\
\hline 1 & $0.83-1.65$ & Poor/Unsatisfactory $(\mathrm{P} / \mathrm{U})$ \\
\hline $\mathrm{O}$ & $0.00-0.82$ & Needs Improvement (NI) \\
\hline
\end{tabular}

The data shows evidence that the classroom instruction and evaluation of the pre-service teachers is "Very Good" with a 4.09 general mean score. An "Excellent" level of performance of the respondents for both students and general observations indicators with 4.29 and 4.09 respectively is an absolute manifestation that they had met, 
and even exceeded, the institutional standards set by the College of Teacher Education along with the teacher and teaching procedure which were rated as "Very Good" respectively.

General observations came out to be the strength of the pre-service teachers, which yielded the highest mean rating they posited (mean $=4.34)$. This manifests an "Excellent" level of classroom instruction and evaluation. It was found that teachers have the capability to create the best class atmosphere (mean $=4.45$ ) to be quality products of the institution. This is a manifestation that pre-service teachers are allocating most importance to the classroom atmosphere. They believe that this is an important component of teaching and learning that helps establish and maintain a good relationship between the teacher and learners. This is also a way to build motivation and confidence among the learners, and to facilitate the processes of teaching and learning.

Table-3a. Practice teaching performance of the pre-service teachers in terms of instructional competencies. ( $N=21)$.

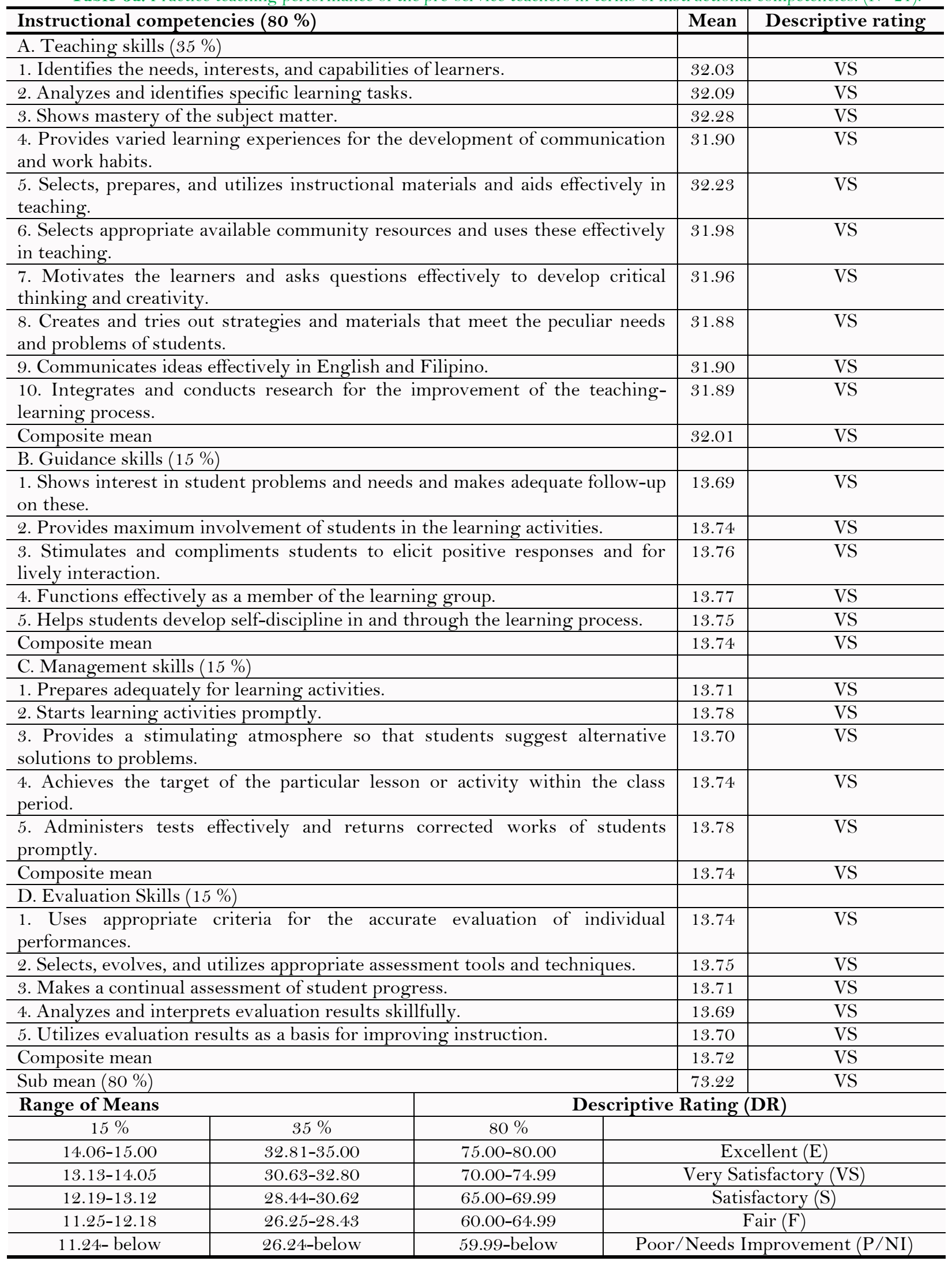

The findings of this study affirm what was proposed by Mojavezi and Tamiz (2012). They pointed out that the relationships between teachers and students also influence the classroom climate. Teachers are responsible for regulating the classroom environment, including managing classroom discipline, implementation of approaches and methods to learning, and interacting with students in the classroom. However, it is essential to note that regarding the ability to answer, the respondents performed "Fair," which is believed to affect their rating performance along with the teacher indicator. The ability to answer is rated when learners ask questions related to the topic as discussed by the practice teacher during demonstration teaching, and the teacher can answer with confidence and certainty. 
Additionally, the respondents were rated highest on the use of teaching aids, with a 4.50 mean score. This implies that the preparation and utilization of instructional materials are among many other trademarks of the preservice teachers of ASIST Bangued Campus. According to Stipek and Daniels (1988), efficient teachers encourage students to understand. They treat student misunderstandings in the subject, and they utilize different visual aids to make the subject more enticing and meaningful.

The results of this study demonstrate that there is still a need to improve the skills and capabilities of student teachers. This was evidenced by the lowest mean rating (3.77) they obtained. Although this mean rating is still within the limits of a "Very Good" level of classroom instruction and evaluation, this was found to be their greatest weakness, especially in their ability to answer questions (mean = 1.64). A "Fair" level of description was obtained from their evaluators. Perhaps these pre-service teachers might have forgotten the principles they had learned regarding what to do when their learners are asking them questions. They might be answering the questions right away. In the opinion of the evaluators, this should not happen. These pre-service teachers need to throw back the questions to their learners to help them think and comprehend.

Problem 3. What is the level of performance in practice teaching of the pre-service teachers in terms of instructional competencies of teaching skills, guidance skills, management skills, and evaluation skills, along with personal and social competencies?

As the table below indicates, the level of pre-service teachers' performance in practice teaching, in terms of their instructional competencies around teaching skills, guidance skills, management skills, and evaluation skills, as rated by their cooperating teachers, is "Very Satisfactory" with a 73.22 sub mean score, which is nearly close to the 75.00-80.00 range of means for "Excellent." This finding only proves that the cooperating teachers were very satisfied with their practice teaching performances, which yielded the highest regard as reflected in the data given by the teachers critiquing their work.

However, the respondents were rated lowest on motivates the learners and asks questions effectively to develop critical thinking and creativity and communicates ideas effectively in English and Filipino, regarding teaching skills and shows interest in student problems and needs and makes an adequate follow-up on these relating to guidance skills.

Provides a permissive and stimulating atmosphere that the students raise and suggest alternative solutions to problems was lowest regarding management skills. Utilizes evaluation results as a basis for improving instruction was rated lowest among the indicators by their cooperating teachers regarding evaluation skills. The slight difference in each of the indicators above revealed only that the level of perceptions of the cooperating teachers differed from one another.

Table $3 \mathrm{~b}$ below discloses the level of performance in practice teaching of the pre-service teachers in terms of personal and social competencies.

Looking at the table, there is a reason to assume, based on the data gathered, that the "Very Satisfactory" level of performance in the practice teaching of the pre-service teachers prevailed, as rated by their cooperating teachers in terms of personal and social Competencies with a sub mean score of 18.34 out of the total percentage for this area. Perceived support from teachers is also a positive predictor of effort in schools, together with the pursuit of social responsibility goals, including acting in pro-social ways that encourage peer cooperation (Wentzel, 1994).

Table-3b. Performance in practice teaching of the pre-service teachers in terms of personal and social competencies.

\begin{tabular}{|c|c|c|c|c|}
\hline \multicolumn{3}{|c|}{ Personal and social competencies (20\%) } & Mean & DR \\
\hline \multicolumn{3}{|c|}{ 1. Observes the teacher's code of ethics and other pertinent rules and regulations. } & 18.36 & VS \\
\hline \multicolumn{3}{|c|}{$\begin{array}{l}\text { 2. Serves as a model in the moral and ethical behavior of students, peers, and the } \\
\text { community. }\end{array}$} & 18.40 & VS \\
\hline \multicolumn{3}{|c|}{ 3. Shows honesty and integrity in actions and activities. } & 18.36 & VS \\
\hline \multicolumn{3}{|c|}{ 4. Accepts and performs leadership roles competently in school and in the community. } & 18.31 & VS \\
\hline \multicolumn{3}{|c|}{ 5. Accepts the role of subordinate whenever the need arises and assumes it intellectually. } & 18.40 & VS \\
\hline \multicolumn{3}{|c|}{ 6. Gets along with students, the school staff, and the community. } & 18.40 & VS \\
\hline \multicolumn{3}{|c|}{ 7. Shows evidence of professional and cultural growth and maturity. } & 18.33 & VS \\
\hline \multicolumn{3}{|c|}{ 8. Participates actively in cultural, professional, and other community activities. } & 18.34 & VS \\
\hline \multicolumn{3}{|c|}{ 9. Shows evidence of sound mental health stability. } & 18.31 & VS \\
\hline \multicolumn{3}{|c|}{ 10. Observes proper grooming and proper health stability. } & 18.38 & VS \\
\hline \multicolumn{3}{|c|}{ 11. Manifests creativeness and resourcefulness in work performance. } & 18.34 & $\mathrm{VS}$ \\
\hline \multicolumn{3}{|c|}{ 12. Prepares and submits neat and accurate reports on time. } & 18.29 & VS \\
\hline \multicolumn{3}{|c|}{ 13. Observes official timeframes. } & 18.30 & VS \\
\hline \multicolumn{3}{|c|}{ 14. Uses free time wisely and lucratively. } & 18.21 & VS \\
\hline \multicolumn{3}{|l|}{ Sub mean $(20 \%)$} & 18.34 & VS \\
\hline \multicolumn{3}{|l|}{ General (100\%) } & 91.56 & $\mathrm{VS}$ \\
\hline \multicolumn{3}{|l|}{ Norm: } & & \\
\hline \multicolumn{5}{|c|}{$\begin{array}{cc}\text { Range of Means } & \text { Descriptive Rating (DR) } \\
\end{array}$} \\
\hline \multicolumn{5}{|c|}{$100 \%$} \\
\hline $18.75-20.00$ & $93.75-100.00$ & \multicolumn{3}{|l|}{ Excellent (E) } \\
\hline $17.50-18.74$ & $87.50-93.74$ & \multicolumn{3}{|l|}{ Very Satisfactory (VS) } \\
\hline $16.25-17.49$ & $81.25-87.49$ & \multicolumn{3}{|l|}{ Satisfactory $(\mathrm{S})$} \\
\hline $15.00-16.24$ & $75.00-81.24$ & \multicolumn{3}{|l|}{ Fair $(\mathrm{F})$} \\
\hline 14.99-below & 74.99-below & \multicolumn{3}{|l|}{ Poor/Needs Improvement (P/NI) } \\
\hline
\end{tabular}


Accepts and performs leadership roles competently in school and in the community, gets along with students, the school staff and the community, and serves as a model in the moral and ethical behavior of students, peers, and the community are among the indicators with a highest mean score of 18.40. Conversely, it can be noted that uses free time wisely and lucratively and prepares and submits a neat and accurate report on time, with 18.21 and 18.29 mean scores respectively, are the lowest indicators revealed in the study.

Problem 4. Is there a significant relationship between the level of GSE of the cooperating teachers and the level of pre-service teachers' classroom instruction and evaluation?

Table-4. Relationship between the level of self-efficacy of the cooperating teachers and the level of pre-service teachers' classroom instruction and evaluation.

\begin{tabular}{c|c|c|c}
\hline Classroom Instruction & R value & R prob & Decision \\
\hline Teacher & 0.271 & $0.234(\mathrm{p}>0.05)$ & Not Significant \\
\hline Teaching Procedure & -0.114 & $0.622(\mathrm{p}>0.05)$ & Not Significant \\
\hline Students & 0.083 & $0.721(\mathrm{p}>0.05)$ & Not Significant \\
\hline General Observation & 0.043 & $0.852(\mathrm{p}>0.05)$ & Not Significant \\
\hline As a whole & -0.062 & $0.791(\mathrm{p}>0.05)$ & Not Significant \\
\hline
\end{tabular}

Table 4 shows that all the correlation coefficients obtained using the Microsoft Excel data analysis Toolpak from the responses of the cooperating teachers and the evaluation received by the practice teachers show that there is no significant relationship existing between the level of self-efficacy of the cooperating teachers and the level of pre-service teachers' classroom instruction and evaluation. This was evidenced by all the $\mathrm{R}$ - computed values with their associated probability of less than 0.05. This means that the level of self-efficacy of the cooperating teachers does not contribute to the level of pre-service teachers' classroom instruction and evaluation. This implies that whether cooperating teachers have high or low self-efficacy, it will not affect the performance of their practice teachers during demonstration teachings. Hence, the self-efficacy of the cooperating teachers is independent to that of the performance of their practice teachers during their final demonstration teaching. This could be due to the fact that before their deployment, they were physically trained, intellectually capable, and emotionally ready as part of the thorough and comprehensive preparations they will have undergone during their earlier years.

However, the fact that no significant relationship existed was not sufficient evidence to conclude that the level of self-efficacy of the cooperating teachers has no direct effect on the level of pre-service teachers' classroom instruction and evaluation. The results of this study support the findings of previous researches suggesting a significant correlation between teacher self-efficacy and increased student achievement, by influencing teachers' instructional practices, enthusiasm, commitment, and teaching behaviors (Tournaki \& Podell, 2005; TschannenMoran \& Hoy, 2001; Wolters \& Daugherty, 2007).

Problem 5. Is there a significant relationship between the level of GSE of the cooperating teachers and the level of performance in practice teaching of the pre-service teachers?

Table-5. Relationship between the level of self-efficacy of the cooperating teachers and the level of performance in the practice teaching of the pre-service teachers.

\begin{tabular}{|c|c|c|c|}
\hline Practice Teaching & R Value & R Prob & Decision \\
\hline I. Instructional competencies & 0.139 & $0.547(\mathrm{p}>0.05)$ & Not Significant \\
\hline A. Teaching skills & 0.852 & $0.043(\mathrm{p}<0.05)$ & Significant \\
\hline B. Guidance skills & 0.090 & $0.699(\mathrm{p}>0.05)$ & Not Significant \\
\hline C. Management skills & 0.798 & $0.050(\mathrm{p} \leq 0.05)$ & Significant \\
\hline D. Evaluation skills & 0.178 & $0.441(\mathrm{p}>0.05)$ & Not Significant \\
\hline II. Personal and social competencies & 0.115 & $0.620(p>0.05)$ & Not Significant \\
\hline As a whole & 0.135 & $0.560(p>0.05)$ & Not Significant \\
\hline
\end{tabular}

Table 5 reveals that significant correlation exists between the level of cooperating teachers' self-efficacy and the level of performance in the practice teaching of the pre-service teachers. Particularly in the instructional competencies of the pre-service teachers along teaching skills, with an R-value of 0.852 with an associated probability of 0.043 higher than 0.05 level of significance. The self-efficacy of these cooperating teachers and the management skills of their pre-service teachers were also found to have a positive correlation with an R-value of 0.798 with the associated probability of 0.050 .

It means that the level of the cooperating teachers' self-efficacy is reliant on the teaching and management skills of the pre-service teachers in their practice teaching career. Therefore, it can be deduced that the higher the level of cooperating teachers' self-efficacy, the more favorable a performance will be observed in the teaching and management skills of the pre-service teachers' practice teaching.

Further, no significant relationship was observed between the guidance and evaluation skills and the personal and social competencies of the pre-service teachers' practice teaching performance, and the level of the cooperating teachers' self-efficacy. It further explains that the high self-efficacy of the cooperating teachers does not influence the level of practice teaching performance of the pre-service teachers, along with the skills and competencies mentioned earlier. Thus, the level of pre-service teachers' practice teaching performance is not directly reliant on whether cooperating teachers are perceived to have a high or low self-efficacy.

Teacher's self-efficacy beliefs may influence a student's achievement in several ways. Teachers with high selfefficacy beliefs are more likely than teachers with a low sense of self-efficacy to implement didactic innovations in the classroom, to use classroom management approaches and adequate teaching methods, to encourage students' autonomy, to take responsibility for students with special learning needs (Allinder, 1994), to manage classroom problems (Chacón, 2005), and to keep students on task (Podell \& Soodak, 1993).

Problem 6. Is there a significant relationship between the level of pre-service teachers' classroom instruction and evaluation and their level of performance in practice teaching? 
Table 6 demonstrates that there is no significant relationship existing between the pre-service teachers' classroom instruction and evaluation, as measured by their supervising instructors and accompanying observers during their demonstration teachings, and their level of performance in practice teaching as rated by their cooperating teachers regarding instructional competencies and personal and social competencies.

It proves that the level of pre-service teachers' classroom instruction and evaluation does not affect the level of performance in practice teaching of the pre-service teachers, or vice versa. The fact there is no significant relationship showing might be due to the fact that the cooperating teachers and the assigned supervising instructors have different ways of grading the subjects based on what is observed by them.

Table-6. Relationship between the pre-service teachers' classroom instruction and evaluation and their performance in practice teaching.

\begin{tabular}{|c|c|c|c|c|c|c|c|}
\hline \multirow{3}{*}{$\begin{array}{c}\text { Classroom Instruction } \\
\text { and Evaluation }\end{array}$} & \multicolumn{6}{|c|}{ Practice Teaching Performance } & \multirow{3}{*}{ As a whole } \\
\hline & \multicolumn{5}{|c|}{ Instructional Competencies } & \multirow{2}{*}{$\begin{array}{c}\text { Personal \& Social } \\
\text { Competencies }\end{array}$} & \\
\hline & TS & GS & MS & ES & IC & & \\
\hline Teacher & 0.010 & -0.028 & -0.060 & -0.021 & -0.016 & -0.114 & 0.037 \\
\hline Teaching Procedure & 0.163 & 0.117 & 0.099 & 0.154 & 0.142 & 0.019 & 0.116 \\
\hline Students & 0.121 & 0.053 & 0.018 & 0.104 & 0.086 & -0.031 & 0.061 \\
\hline Gen. Observation & 0.071 & 0.043 & 0.019 & 0.072 & 0.056 & -0.063 & 0.031 \\
\hline As a whole & 0.100 & 0.050 & 0.020 & 0.085 & 0.074 & -0.051 & 0.047 \\
\hline
\end{tabular}

Note: Legend

* - Significant at 0.05 Level

** - Significant at 0.01 Level

\section{Conclusions}

Based on the salient findings of the study, the following conclusions were drawn:

Cooperating teachers have a strong determination to deal with academic-related challenges which they encountered, and also to manage personal conflicts, but they do not compromise being open-minded to someone opposing them. The pre-service teachers meet the standards set by the college regarding the different competencies in their preparation for actual teaching. Their strengths are in the use of teaching aids, while their weaknesses lie in the ability to answer questions. The GSE of the cooperating teachers does not mediate with the level of pre-service teachers' classroom instruction and evaluation performance. The teaching and management skills of the pre-service teachers are brought about by the relatively high self-efficacy of their cooperating teachers in a mediating role.

\section{References}

Allinder, R. M. (1994). The relationship between efficacy and the instructional practices of special education teachers and consultants. Teacher Education and Special Education, 17(2), 86-95.Available at: https://doi.org/10.1177/088840649401700203.

Anthony, R., \& Said, H. (2008). A comparative study of the pre-service teachers' self-efficacy based on the field experience. Retrieved from: http://eprints.utm.my/7895/.

Baker, P. H. (2002). The role of self-efficacy in teacher readiness for differentiating discipline in classroom settings. Unpublished Dissertation.

Bandura, A. E. (1995). Self-efficacy in changing societies. Paper presented at the 3rd Annual Conference held at the Johann Jacobs Foundation Communication Ctr, Marbach Castle, Germany, Nov 4-6, 1993. Cambridge University Press.

Chacón, C. T. (2005). Teachers' perceived efficacy among English as a foreign language teachers in middle schools in Venezuela. Teaching and Teacher Education, 21(3), 257-272.Available at: https://doi.org/10.1016/j.tate.2005.01.001.

Cheng, E. C. (2013). Enhancing the quality of pre-service teachers' learning in teaching practicum. Unpublished Manuscript, The Hong Kong Institute of National Library.

Cherry, K. (2018). Self efficacy and why believing in yourself matters. Retrieved from: https://www.verywellmind.com/what-is-self-efficacy2795954.

DesMarais, C. (2012). 15 Women to watch in tech. Retrieved from: http://www.inc.com/ss/christina-desmarais/15-women-watch-techstartups.html\#11. [Accessed January 14, 2019].

Garvis, \& Keogh. (2011). Pre-service student-teacher self-efficacy beliefs: An insight into the making of teachers. Australian Journal of Teacher Education, 36(12), 46-57.

Guo, Y., Connor, C. M., Yang, Y., Roehrig, A. D., \& Morrison, F. J. (2012). The effects of teacher qualification, teacher self-efficacy, and classroom practices on fifth graders' literacy outcomes. The Elementary School Journal, 113(1), 3-24.Available at: https://doi.org/10.1086/665816.

Inceçay, G., \& Dollar, Y. K. (2013). Classroom management, self-efficacy and readiness of Turkish pre-service English teachers. ELT Research Journal, 1(3), 189-198.

Liaw, E.-C. (2009). Teacher efficacy of pre-service teachers in Taiwan: The influence of classroom teaching and group discussions. Teaching and Teacher Education, 25(1), 176-180.Available at: https://doi.org/10.1016/j.tate.2008.08.005.

Mahler, D., Großschedl, J., \& Harms, U. (2017). Opportunities to learn for teachers' self-efficacy and enthusiasm. Education Research International, 2017, 1-17.Available at: 10.1155/2017/4698371.

Martin, A. J., \& Marsh, H. W. (2006). Academic resilience and its psychological and educational correlates: A construct validity approach. Psychology in the Schools, 43(3), 267-281.Available at: https://doi.org/10.1002/pits.20149.

Mojavezi, A., \& Tamiz, M. P. (2012). The impact of teacher self-efficacy on the students' motivation and achievement. Theory and Practice in Language Studies, 2, 483-491.Available at: https://doi.org/10.4304/tpls.2.3.483-491.

Molnar, K. (2008). A peer collaborative instructional design for increasing teaching efficacy in pre-service education majors. Unpublished Dissertation. Walden University.

Montebon, D. R. (2015). A needs assessment survey on teacher readiness of science pre-service teachers: Towards a contextualized Student Teaching Enhancement Program (STEP). International Journal of Learning, Teaching and Educational Research, 10(3), 17-26.

Muijs, R. D., \& Rejnolds, D. (2001). Teachers' beliefs and behaviors: What really matters. Journal of Classroom Interaction, 37(50), 25-40.

Nauta, M. M. (2004). Self-efficacy as a mediator of the relationships between personality factors and career interests. Journal of Career Assessment, 12(4), 381-394.Available at: https://doi.org/10.1177/1069072704266653.

Podell, D. M., \& Soodak, L. C. (1993). Teacher efficacy and bias in special education referrals. The Journal of Educational Research, 86(4), 247253.Available at: http://dx.doi.org/10.1080/00220671.1993.994183.

Skaalvik, E. M., \& Skaalvik, S. (2004). Self-concept and self-efficacy: A test of the internal/external frame of reference model and predictions of subsequent motivation and achievement. Psychological Reports, 95(3_suppl), 1187-1202.Available at: https://doi.org/10.2466/pro.95.3f.1187-1202.

Stipek, D. J., \& Daniels, D. H. (1988). Declining perceptions of competence: A consequence of changes in the child or in the educational environment? Journal of Educational Psychology, 80(3), 352-356.Available at: https://doi.org/10.1037/0022-0663.80.3.352.

Tournaki, \& Podell. (2005). The impact of student characteristics and teacher efficacy on teachers' predictions of student success. Retrieved from:

https:// www.researchgate.net/ 
publication/234745744_The_Impact_of_Student_Characteristics_and_Teacher_Efficacy_on_Teachers'_Predictions_of_Student_S uccess.

Tschannen-Moran, M., \& Hoy, A. W. (2001). Teacher efficacy: Capturing an elusive construct. Teaching and Teacher Education, 17(7), 783805.Available at: https://doi.org/10.1016/s0742-051x(01)00036-1.

Tschannen-Moran, M., Hoy, A. W., \& Hoy, W. K. (1998). Teacher efficacy: Its meaning and measure. Review of Education, 68(2), 202248.Available at: https://doi.org/10.3102/00346543068002202.

Wentzel, K. R. (1994). Relations of social goal pursuit to social acceptance, classroom behavior, and perceived social support. Journal of Educational Psychology, 86(2), 173-182.Available at: https://doi.org/10.1037/0022-0663.86.2.173.

Wolters, C. A., \& Daugherty, S. G. (2007). Goal structures and teachers' sense of efficacy: Their relation and association to teaching experience and academic level. Journal of Educational Psychology, 99(1), 181-193.Available at: https://doi.org/10.1037/o0220663.99.1.181. 